\title{
Hormonal control of IGF-binding protein (IGFBP)-5 and IGFBP-2 secretion during differentiation of the HC11 mouse mammary epithelial cell line
}

\author{
K Phillips, M A Park, L H Quarrie, M Boutinaud, J D Lochrie, D J Flint, G J Allan \\ and $\mathbf{J}$ Beattie
}

Molecular Recognition Group, Hannah Research Institute, Ayr KA6 5HL, UK

(Requests for offprints should be addressed to J Beattie; Email: beattiej@ hri.sari.ac.uk)

M Boutinaud is currently at INRA, F-35590 Saint Gilles, France

\begin{abstract}
The mouse mammary epithelial cell line $\mathrm{HC} 11$ upregulates the synthesis of $\beta$-casein (a differentiation marker) following treatment with the lactogenic hormone mix dexamethasone, insulin and prolactin (DIP). We demonstrate that the basal levels of IGF-binding protein (IGFBP)- 5 secreted by undifferentiated HC11 cells are upregulated 10-fold during DIP-induced cellular differentiation whereas the level of the other IGFBP species secreted by HC11 cells (IGFBP-2) is downregulated during this process. As previously reported, the combination of all three of these hormones is required for synthesis of the differentiation marker $\beta$-casein, whereas basal IGFBP- 5 secretion is evident in the absence of any hormonal treatment and, unlike $\beta$-casein, secretion of this protein can be stimulated by binary combinations of the hormones (although maximal levels of IGFBP-5 are achieved in the presence of all three lactogenic hormones). Additionally, levels of IGFBP-5 can be increased by DIP treatment under conditions (non-competency of $\mathrm{HC} 11$ cultures or presence of epidermal growth factor) where DIP treatment does not increase synthesis of $\beta$-casein. For IGFBP-2, dexamethasone is a potent inhibitor of secretion whilst prolactin stimulated the secretion of this binding protein into the medium. For the IGFBP axis in $\mathrm{HC} 11$ cells we conclude that, although the levels of IGFBP-5 and -2 are influenced by the state of cellular differentiation, the hormonal regulation of the levels of these IGFBP species can be dissociated from the regulation of $\beta$-casein synthesis. In a further series of experiments we demonstrate that IGF-I is able to replace insulin in the DIP lactogenic hormone mix and by the use of a specific IGF-I receptor blocking antibody indicate that the action of IGF-I is mediated through the cell surface IGF-I receptor and not by cross-reaction of IGF-I ligand at the insulin receptor. We discuss our data in the context of the potential role of the IGF axis in the process of cell differentiation and illustrate the significance of our findings in the context of the physiology and life cycle of the mammary epithelial cell.
\end{abstract}

Journal of Molecular Endocrinology (2003) 31, 197-208

\section{Introduction}

The growth, development and involution of the mammary gland during cycles of pregnancy and lactation is a carefully co-ordinated process which is under multi-factorial control. Predominant among the endocrine factors involved in this process are the pituitary hormones prolactin and growth hormone along with the ovarian steroids, oestradiol and progesterone. In recent years, however, much interest has focused on the role of the insulin-like growth factors (IGFs) in the regulation of mammary gland biology and several lines of evidence support an endocrine or paracrine role for these small polypeptide hormones in this process (Ruan et al. 1992, LeRoith et al. 1995, Hadsell et al. 1996, Neuenschwander et al. 1996, Kleinberg 1998, Ruan \& Kleinberg 1999, Bonnette \& Hadsell 2001). The activity of IGF-I and IGF-II in the mammary gland, and in other tissues, is 
modulated by the presence of IGF-binding proteins (IGFBPs). There are six well-characterised IGFBPs, which bind IGFs with high affinity. The sequestration of IGF ligand by IGFBPs can inhibit the interaction of IGFs with their cognate cell surface receptors, and this process is aided by the fact that IGFBPs exhibit an affinity for IGFs which is an order of magnitude higher than that of the cell membrane IGF-I receptor (IGF-IR) $(\sim 0 \cdot 1$ vs $1 \mathrm{nM})$. However, under some circumstances IGFBPs have also been reported to enhance the activity of IGF-I, a function which may be associated with the ability of some IGFBPs to bind to extracellular matrix proteins or directly to cell membranes (reviewed in Clemmons 1998).

In the light of the above observations reporting an essential and stimulatory role for IGF-I in mammary gland development, and in particular in mammary epithelial cell survival, the recent findings of increased IGFBP-5 expression by involuting rodent mammary gland are of particular significance (Tonner et al. 1995, 1997). These studies have suggested that the large concentrations of IGFBP-5 present in the mammary gland during involution may act to neutralise the function of IGF-I as a survival factor for mammary epithelial cells and that IGFBP-5 may therefore be instrumental in initiating the process of mammary gland involution (Flint et al. 2000, Tonner et al. 2000). These findings are important in the ongoing investigation into the biology of this important molecule, many of whose properties have been the subject of an excellent recent review (Schneider et al. 2002). In the case of the involuting mammary gland, a molar excess of IGFBP-5 to IGF-I within the tissue or the paracellular environment leads intuitively to the conclusion of inhibition of IGF activity. However, it has also been shown that expression of IGFBP-5 and the subsequent function of IGFBP-5 protein is associated with stimulatory effects on the processes of proliferation, activation and differentiation of other cell and tissue types (Cheng et al. 1999, Richman et al. 1999, Kanatani et al. 2000). Further to this, it is believed that the ability of IGFBP-5 to associate with extracellular matrix components and to exert IGF-independent effects through a specific cell surface receptor (Jones et al. 1993, Andress 1998) may be important for the stimulatory effects of this binding protein.
The dual nature of IGFBP-5 activity as a pro-apoptotic protein and also as a gene expressed in some instances of cellular differentiation may have important consequences during the course of mammary gland growth, differentiation and involution. In order to examine this role we have conducted studies on the mouse mammary epithelial cell line HC11. This cell line was derived from the heterogeneous Comma 1-D line isolated from a mid-pregnant Balb/c mouse (Danielson et al. 1984). HC11 cells which are grown to confluence in medium containing epidermal growth factor (EGF) and insulin have the ability to respond to a lactogenic hormone mix (dexamethasone, insulin and prolactin (DIP)) by synthesising the milk protein $\beta$-casein, a marker of epithelial cell differentiation (Ball et al. 1988a,b). Although (uniquely amongst mammary epithelial cell lines) HC1 1 cells are able to differentiate when seeded in the absence of added substratum, the cells do secrete extracellular matrix proteins, amongst which laminin and tenascin have been identified, and the appropriate organisation of this endogenously secreted matrix is important for cellular differentiation following challenge with lactogenic hormone mix (Chammas et al. 1994). Although the importance of the IGF axis in mammary gland development is well-established through the various in vivo studies described above, in the context of mammary epithelial cells much of the work in relation to IGF and IGFBPs has focused on human breast cancer cell lines (Yamanaka et al. 1999, McCaig et al. 2002). There are few data in relation to the role of the IGF axis in the regulation of growth, differentiation and apoptosis in differentiating mammary cell lines such as HC11 cells. In the current report we describe the characterisation of the IGFBP profile in relation to undifferentiated and differentiated HC11 cells and dissect the hormonal regulation of the two principal IGFBPs secreted by differentiated and undifferentiated HC11 cells (IGFBP-5 and -2). We also show a dissociation between the process of cellular differentiation and IGFBP secretion profile. In addition, we examine the effectiveness of IGF-I in stimulating the differentiation of $\mathrm{HCll}$ cells. We discuss our data in the context of mammary gland differentiation and involution and also the wider implications of the role of IGFBP-5 in cellular differentiation. 


\section{Materials and methods}

\section{Materials}

The mouse mammary epithelial cell line HC11 (Danielson et al. 1984) was a kind gift from Dr Bruce Whitelaw, Roslin Institute, Edinburgh. Sheep anti-human/rat IGFBP-5 antiserum was generated 'in-house' and has been described previously (Tonner et al. 1997). Anti-bovine IGFBP-2 (Cat. No. 06-107) was from Upstate Biotech (Charlottesville, VA, USA). Animal/media grade human IGF-I (Product No. 1 M001) and IGF-II (Product No. 0 M001) were from GroPep Ltd (Adelaide, Australia). Bovine insulin (I-6634), dexamethasone (D-4902), ovine prolactin (L-6520) and EGF (E-4127) were from Sigma (Poole, Dorset, UK). $\mathrm{Na}^{125} \mathrm{I}$ (Product No. 63034) was from ICN (Basingstoke, Hants, UK). Rabbit anti-mouse $\beta$-casein antibody was a kind gift from Dr Ernst Reichmann (University of Zurich). An in-house sheep anti-rat $\beta$-casein antibody was also generated as described below. Anti-human IGF-IR monoclonal antibody (Mab) (Product No. 391), mouse IGFBP-5 and -2 (Product Nos 578-B5-025 and 797-B2-025 respectively) were from R\&D Systems (Abingdon, Oxon, UK). Tissue culture plasticware was from Corning Costar (High Wycombe, Bucks, UK). DMEM (phenol red-free, 31053-028), penicillin/streptomycin (PenStrep) (15140-122), L-glutamine (25030-024) and fetal calf serum were from Gibco/Invitrogen (Paisley, Strathclyde, UK). Sodium pyruvate (P-2256) and Protease Inhibitor Cocktail (P-8340) were from Sigma. All other reagents were of analytical grade.

\section{Methods}

\section{Tissue culture}

HC11 cells were grown and treated essentially as described previously (Chammas et al. 1994) with the following modifications. HC11 cells were grown to confluence in 12-well culture dishes (over a period of 2-3 days) in $1 \mathrm{ml}$ complete medium - DMEM (phenol red-free), 10\% fetal calf serum, $100 \mathrm{U} / \mathrm{ml}$ penicillin/streptomycin, $2 \mathrm{mM}$ glutamine, $1 \mathrm{mM}$ sodium pyruvate, $5 \mu \mathrm{g} / \mathrm{ml}$ insulin, $10 \mathrm{ng} / \mathrm{ml} \mathrm{EGF}$. Insulin and EGF are required in culture medium to produce competent cultures which are able to respond to treatment with lactogenic hormones. After 2 days at confluence, competent cell cultures were induced to differentiate by treatment, under serum-free medium (SFM) conditions, with phenol red-free DMEM containing $5 \mu \mathrm{g} / \mathrm{ml}$ insulin, $5 \mu \mathrm{g} / \mathrm{ml}$ prolactin and $1 \mu \mathrm{M}$ dexamethasone (500 $\mathrm{l} / \mathrm{well})$. Incubations were continued for typically 2-4 days at which time conditioned medium was removed for analysis of IGFBP profile and cell monolayers were lysed for the analysis of $\beta$-casein synthesis. Under these conditions, differentiation of HC11 cells as monitored by $\beta$-casein synthesis was reversible following removal of the lactogenic stimulus. Control, undifferentiated HC11 cell cultures were obtained by culturing competent cells in phenol red-free DMEM in the absence of lactogenic hormones. In some experiments, insulin was replaced by IGF-I or IGF$\mathrm{II} \pm$ anti-IGF-IR Mab. The concentrations of these reagents are indicated in the relevant figures and accompanying legends.

\section{Cell lysis}

Cell monolayers were lysed in $200 \mu$ l of buffer containing $50 \mathrm{mM}$ Tris-HCl (pH 7·4), $150 \mathrm{mM}$ NaCl, $1 \%$ Triton-X100, 2 mM EDTA, 0.33\% (v/v) Protease Inhibitor Cocktail. Lysates were centrifuged for $15 \mathrm{~min}$ at $15800 \mathrm{~g}$ in a bench-top Eppendorf centrifuge at $4{ }^{\circ} \mathrm{C}$ and supernatants were removed and stored at $-20{ }^{\circ} \mathrm{C}$ prior to analysis for $\beta$-casein protein. Routinely $10 \mu$ lysate were electrophoresed under reducing conditions and blotted for $\beta$-casein as described below.

\section{Western and ligand blotting}

Conditioned medium was removed from cell monolayers and centrifuged briefly to remove cellular debris. Typically $10 \mu \mathrm{l}$ conditioned medium or cell lysate were mixed with $\times 4$ NuPage LDS sample buffer (Gibco/Invitrogen, Paisley, Strathclyde, UK) (non-reducing for ligand blotting; reducing for Western blotting). Electrophoresis and transfer were performed using the Novex pre-cast gel system (Gibco/Invitrogen) as described previously (Bramani et al. 1999). Western blots of cellconditioned medium with anti-IGFBP-5 were performed in Tris-buffered saline $(20 \mathrm{mM}$ Tris$\mathrm{HCl}, 137 \mathrm{mM} \mathrm{NaCl}, \mathrm{pH} 7 \cdot 6$ ) with $0 \cdot 1 \%$ Tween 20 (TBS-T). After blocking for $1 \mathrm{~h}$ in TBS-T/3\% BSA, filters were incubated with anti-IGFBP-5 antiserum at a dilution of 1:2000 for $1 \mathrm{~h}$ at room 
temperature or overnight at $4{ }^{\circ} \mathrm{C}$. Following washes in TBS-T (six times $15 \mathrm{~min}$ ), blots were probed with horseradish peroxidase (HRP)-conjugated anti-sheep (1:5000) in TBS-5\% dried milk for $1 \mathrm{~h}$ at room temperature and then developed with enhanced chemiluminescence reagents. Western blots of conditioned medium for IGFBP-2 and of cell lysates for $\beta$-casein were performed in a similar manner with the inclusion of $1 \%$ fish gelatin and $1 \%$ BSA in TBS-T buffer for blocking and antibody dilution. The presence of fish gelatin in buffers considerably reduced background levels in IGFBP-2 and $\beta$-casein blots. Primary antibodies were used at a dilution of 1:1000 (or occasionally $1: 2000$ for Reichmann anti- $\beta$-casein antibody). HRP-conjugated anti-rabbit secondary antibody was used at a dilution of 1:5000 for $\beta$-casein blots (Reichmann) and 1:10 000 for IGFBP-2 blots. Blots using the in-house sheep anti-rat $\beta$-casein blots were developed with anti-sheep-HRP at a dilution of 1:5000. Ligand blots of conditioned media were performed according to the method originally described by Hossenlopp et al. (1986).

\section{$R I A$}

Levels of IGFBP-2 and IGFBP-5 in undifferentiated and differentiated HC11 cell-conditioned medium were determined by RIA with the antibodies which were used for Western blotting. For IGFBP-2 RIA, approximately 25000 c.p.m. ${ }^{125}$ I-IGFBP-2 $(100 \mu \mathrm{l})$ in RIA buffer $(50 \mathrm{mM}$ $\mathrm{NaH}_{2} \mathrm{PO}_{4}$ (pH 7.4) $150 \mathrm{mM} \mathrm{NaCl}, 2 \mathrm{mM}$ EDTA, $0.025 \%$ (w/v) sodium azide) and $0-45 \mathrm{ng} / \mathrm{ml}$ unlabelled mouse IGFBP-2 protein were incubated with primary antibody $(1: 5000)$ in a final volume of $300 \mu \mathrm{l}$. Immune complexes were precipitated by the addition of $300 \mu \mathrm{l}$ anti-rabbit precipitating antiserum (RIA buffer: 16\% PEG:anti-rabbit $\gamma$-globulin:

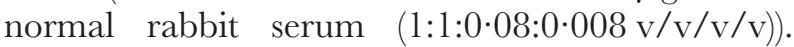
Following a $1 \mathrm{~h}$ incubation at room temperature and centrifugation $(1700 \boldsymbol{g}$ for $30 \mathrm{~min})$, supernatants were decanted and radioactivity in pellets determined by $\gamma$-counting. An identical protocol was used in RIA of IGFBP-5 with the exception that IGFBP-5 standards were present over a concentration range of $0-750 \mathrm{ng} / \mathrm{ml}$ and precipitating antiserum contained anti-sheep $\gamma$-globulin and normal sheep serum. There was no crossreactivity of IGFBP-2 or -5 in respective RIAs. For IGFBP-5 RIA, intra- and inter-assay coefficients of variance (determined at $\mathrm{ED}_{50}$ ) were $13 \cdot 1$ and $16 \cdot 8 \%$ respectively; $\mathrm{ED}_{50}$ was $41.5 \pm 4.37 \mathrm{ng} / \mathrm{ml}$ $(n=4 \pm$ S.E.). For IGFBP-2 RIA, intra- and interassay coefficients of variation (determined at $\mathrm{ED}_{50}$ ) were 12.5 and $19.5 \%$ respectively and $\mathrm{ED}_{50}$ was $1.53 \pm 0.17 \mathrm{ng} / \mathrm{ml} \quad(n=4 \pm$ S.E.). Samples of conditioned medium were assayed at appropriate dilutions to fall into the range of the standard curves and to ensure parallelism in the assay and all samples from individual experiments were analysed in a single assay.

\section{Generation of sheep anti-rat $\beta$-casein antiserum}

Two sheep were immunised with purified rat $\beta$-casein in complete Freund's adjuvant and thereafter boosted at intervals of 21 days with rat $\beta$-casein in incomplete Freund's adjuvant. Sheep received $100 \mu \mathrm{g}$ immunogen administered as six $500 \mu \mathrm{l}$ s.c. injections.

\section{lodination}

Mouse IGFBP-2 and IGFBP-5 and human IGF-I were iodinated to a specific activity of approximately $100 \mu \mathrm{Ci} / \mu \mathrm{g}$ by the iodogen-coated tube method (Fraker \& Speck 1978). Unincorporated ${ }^{125} \mathrm{I}$ was separated from protein-bound isotope by gel filtration over a $3 \mathrm{ml}$ gel column of Sephadex G10. The authenticity of radiolabeled protein was confirmed by trichloroacetic acid precipitation of product, which resulted in values typically between 80 and $90 \%$ counts precipitated.

\section{Statistics}

Differences in IGFBP-2 and IGFBP-5 levels following treatment of $\mathrm{HCll}$ cells with various hormonal combinations (as determined by RIA) were analysed using Student's $t$-test and were considered significant at $P<0 \cdot 01$.

\section{Results}

Initial analysis of the profile of IGFBP secretion by undifferentiated and differentiated cultures of HC11 cells was undertaken using ligand blotting with ${ }^{125}$ I-IGF-II and Western blotting with specific antisera to IGFBP-5 and -2 . The results of these experiments are shown in Fig. 1, where we analysed conditioned medium from quadruplicate 


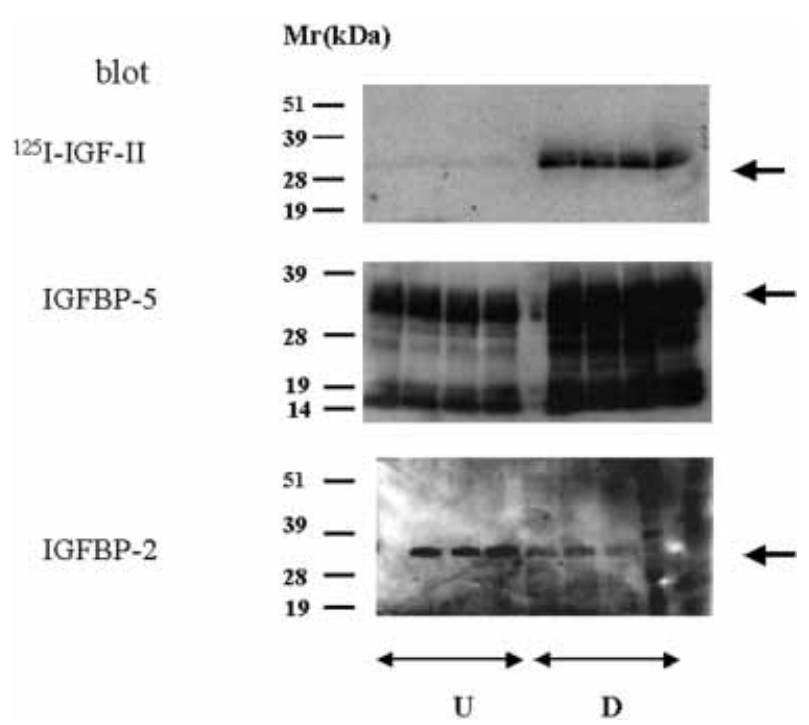

Figure 1 Medium conditioned for $48 \mathrm{~h}$ by undifferentiated (U) or differentiated (D) HC11 cells $(10 \mu \mathrm{l})$ was analysed by ${ }^{125} \mathrm{I}-\mathrm{IGF}-\mathrm{II}$ ligand blotting (upper panel). A binding protein specie(s) of molecular mass $\sim 30 \mathrm{kDa}$ which is upregulated in differentiated medium was identified (arrow). Western blot analysis (middle panel) identifies IGFBP-5 present in undifferentiated medium and the upregulation of this IGFBP species in medium conditioned by differentiated cells. IGFBP-2 (bottom panel) is also detected in $\mathrm{HC} 11$ cell-conditioned medium by Western blot with anti-IGFBP-2-specific antiserum. The levels of this binding protein are downregulated in medium from differentiated cells. Cells were allowed to condition the medium for a period of $48 \mathrm{~h}$. This experiment was repeated three times and a representative blot is shown.

(or triplicate, IGFBP-2) wells of undifferentiated and differentiated cell cultures. Ligand blot (upper panel) analysis indicates the presence of an IGFBP specie(s) whose levels are clearly upregulated in medium conditioned by differentiated HC11 cells. Identification of the IGFBP species produced by undifferentiated and differentiated HC11 cells was achieved using western blotting with specific anti-IGFBP antibodies. Figure 1 illustrates the results of such an experiment where conditioned medium from undifferentiated or differentiated HC11 cell cultures was probed with an antiserum to IGFBP-5 (middle panel) or anti-IGFBP-2 (lower panel). These data clearly identify IGFBP-5 as a binding protein species which is present in medium conditioned by undifferentiated $\mathrm{HCll}$ cells and which is upregulated during HC11 cell differentiation. It is also apparent that there are lower molecular mass immunoreactive fragments

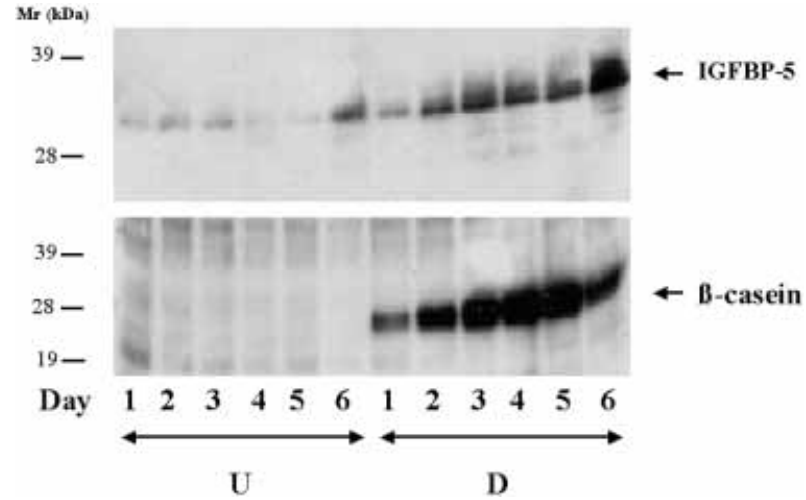

Figure 2 Time course of IGFBP-5 secretion and $\beta$-casein synthesis by $\mathrm{HC} 11$ cells. Conditioned medium and $\mathrm{HC} 11$ cell lysates derived from undifferentiated $(\mathrm{U})$ or differentiated (D) HC11 cells were analysed for IGFBP-5 and $\beta$-casein respectively at $24 \mathrm{~h}$ intervals over the time period $0-6$ days.

detected by blotting with the anti-IGFBP-5 antiserum which do not bind IGF-II and are therefore not detected by ligand blot analysis. Competitive Western analysis confirmed these fragments as proteolytic fragments of native full-length IGFBP-5 (data not shown). IGFBP-2 is also present in medium conditioned by undifferentiated cells, although levels of this IGFBP are downregulated during DIP-induced HC11 cell differentiation (Fig. 1, lower panel). It is important to note that no cross-reactivity was seen between the anti-IGFBP-2 and anti-IGFBP-5 antisera. The higher molecular mass doublet ( 40-45 kDa) typically presented by IGFBP-3 was not present in medium conditioned by either undifferentiated or differentiated HC11 cells and there is no evidence by ligand blot for a lower molecular mass IGFBP species at $\sim 24 \mathrm{kDa}$ characteristic of mouse IGFBP-4 (Boney et al. 1994). We are unable to comment on the presence of either IGFBP-1 or IGFBP-6 in conditioned medium as in our hands anti-peptide antisera to these mouse IGFBPs did not react with appropriate positive controls. The secretion of IGFBP-5 by differentiated HC11 cells was confirmed in a time course experiment (Fig. 2) where IGFBP-5 accumulation in conditioned medium from differentiated and undifferentiated cultures was examined over a 0-6 day time period, and was analysed in parallel with blots of cell lysates for $\beta$-casein synthesis (a marker of HC11 cell differentiation) over the same time frame. IGFBP-5 clearly accumulated in cultures up to 

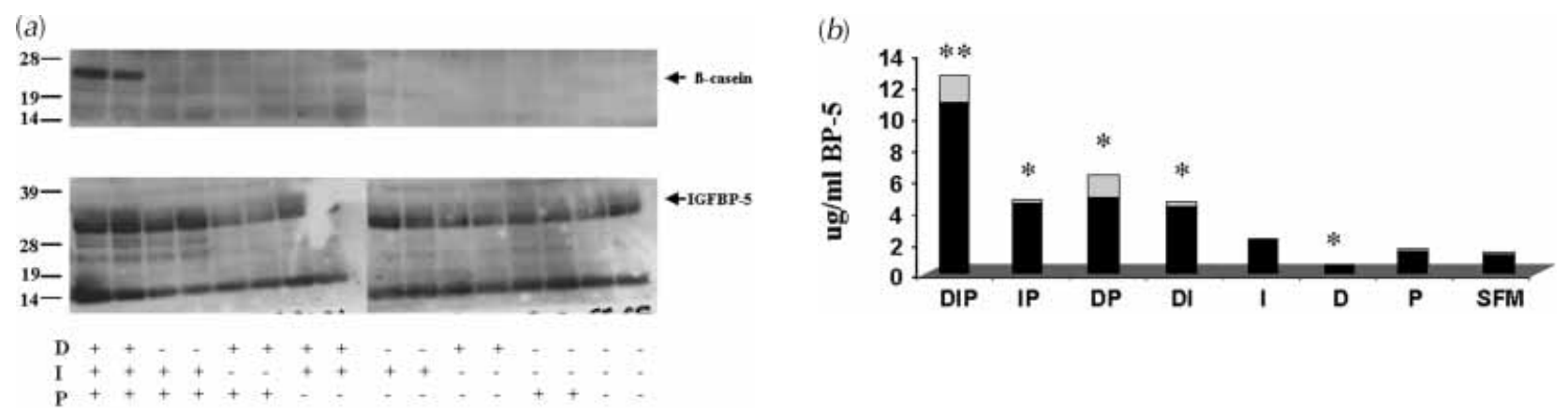

Figure 3 Regulation of IGFBP-5 secretion and $\beta$-casein synthesis can be dissociated in differentiating HC11 cells. (a) The effect of dexamethasone (D), insulin (I) or prolactin (P) on IGFBP-5 and $\beta$-casein synthesis was tested alone or in binary and tertiary combinations of the hormones. Western blots of conditioned medium or cell lysates for IGFBP-5 or $\beta$-casein respectively were performed and the results of duplicate wells for each treatment are shown. Treatment period was 4 days. This experiment was repeated five times and a representative blot is shown.

(b) Quantification of IGFBP-5 levels in HC11-conditioned medium by specific RIA. Three experiments were performed with duplicate wells for each treatment and data are pooled as mean \pm S.E. (light shading). ${ }^{*} P<0 \cdot 01,{ }^{* *} P<0 \cdot 001$ (Student's $t$-test) compared with SFM cultures.

6 days, showing a similar pattern to the kinetics of intracellular $\beta$-casein accumulation, although there was a decrease in $\beta$-casein levels at day 6 . Again it is apparent that there is a basal level of IGFBP-5 detectable in undifferentiated cell cultures which appears to increases on day 6 of SFM culture. Although proteolysis of IGFBP-5 is again evident is does not appear as extensive as that depicted in Fig. 1 (middle panel).

In order to further examine the regulation of IGFBP secretion by HC11 cells we examined the contribution of each of the components of the lactogenic mix in the control of IGFBP secretion. Evidence presented in Figs 1 and 2 clearly indicates secretion of IGFBP-5 under basal (DIP-free) conditions where $\beta$-casein synthesis is undetected (see for example lanes U1-U6 in Fig. 2). We wished to examine further whether we could dissociate the differentiation of HC11 cells (using $\beta$-casein synthesis as a marker) from the IGFBP profile in these cultures. The experiment described in Fig. 3a shows a representative Western blot from an experiment where the levels of intracellular $\beta$-casein and secreted IGFBP-5 were monitored following treatment of competent HCl1 cells with tertiary, binary and single combinations of the lactogenic hormones. The results clearly show that the complete lactogenic complement of hormones (DIP) is required for $\beta$-casein synthesis in HC11 cells (upper panel). In a similar fashion the strongest signal on Western blots of IGFBP-5 is also seen in equivalent HC11 cell cultures which have been treated with DIP. However, there is also a stimulation of IGFBP-5 levels when HC11 cells are treated with binary combinations of hormones (although low in the representative blot depicted in Fig. 3a, repeat experiments indicated that the binary combination of dexamethasone and prolactin was also stimulatory for IGFBP-5 levels - see Fig. 3b). As treatment with binary combinations of dexamethasone, insulin and prolactin does not stimulate $\beta$-casein synthesis it suggests a further dissociation between the differentiation of this cell line and the observed profile of IGFBP secretion. Although the effects of single hormone treatments were less obvious, insulin alone appeared to have a small stimulatory effect on IGFBP-5 secretion and dexamethasone appeared to inhibit secretion. Because of the technical difficulty in accurate quantification of the levels of IGFBP-5 by densitometric analysis of Western blots of conditioned medium derived from differentially treated cell cultures, we established an IGFBP-5 RIA and used this method to more precisely quantify the levels of IGFBP-5 in conditioned medium (see Materials and methods). In Fig. 3b we report the levels of IGFBP-5 in HC11-conditioned medium from cells treated as described in Fig. 3a and as determined in pooled data from three separate experiments. These data qualitatively support the findings of Western blot data and show a range of IGFBP-5 concentrations of $\sim 1-12 \mu \mathrm{g} / \mathrm{ml}$ in conditioned medium and indicate a 10-fold increase in IGFBP-5 levels following HC11 cell 
(a)

Mr (kDa)

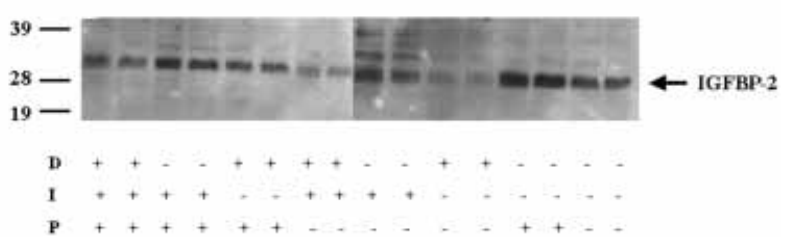

(b)

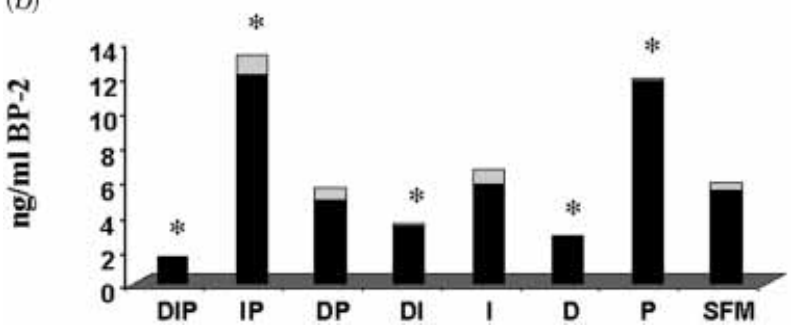

Figure 4 (a) Regulation of IGFBP-2 secretion by treatment with dexamethasone (D), insulin (I) or prolactin (P) alone or in binary and tertiary combination. Western blots of conditioned medium were performed with anti-IGFBP-2 antisera and the results of duplicate wells for each treatment are shown. Treatment period was 4 days. This experiment was repeated five times with similar results in each case. A representative blot is presented. (b) RIA of IGFBP-2 levels in HC11-conditioned medium. Three experiments were performed with duplicate wells for each treatment and data are pooled as mean \pm S.E. (light shading) ${ }^{*} P<0.01$ compared with SFM cultures (Student's $t$-test).

differentiation (compare SFM vs DIP in Fig. 3b) with intermediate concentrations of IGFBP-5 following treatments with binary combinations of hormone. As indicated above, this pooled RIA data indicated a statistically significant reduction in IGFBP-5 levels following treatment of competent HC11 cells with dexamethasone alone. There was also a stimulatory effect of insulin alone on IGFBP-5 levels, although this was not statistically significant.

A Western blot analysis of IGFBP-2 levels in HC11 cell-conditioned medium indicated that dexamethasone was consistently inhibitory for secretion of this binding protein and that prolactin reproducibly stimulated the secretion of IGFBP-2 (Fig. 4a and b). Therefore the levels of IGFBP-2 which are present in binary and tertiary combinations of hormonal treatments are largely determined by the balance of the stimulatory effect of prolactin and the inhibitory effect of dexamethasone (see Discussion). In HC11 cells which are treated with insulin alone there is also evidence of higher molecular mass proteins which cross-react with the anti-IGFBP-2 antiserum. These bands are also evident to a lesser extent in other treatments (e.g. insulin+prolactin). These higher molecular mass bands were reproducibly seen in repeat experiments but their identity is unknown. However, perhaps the most significant finding from RIA experiments was the observation that levels of IGFBP-2 in HC11-conditioned medium were three orders of magnitude lower than the values obtained for IGFBP-5 (ng/ml IGFBP-2 vs $\mu \mathrm{g} / \mathrm{ml}$ IGFBP-5) and these data explain the results obtained during ligand blot analysis of undifferentiated and differentiated HCl1 cell medium. As the level of IGFBP-5 is three orders of magnitude higher than IGFBP-2, and as IGFBP-5 is upregulated in differentiated $\mathrm{HC} 11$ cell cultures, band intensity following ligand blot analysis of conditioned medium will largely reflect the presence of IGFBP-5 and will clearly be more intense in medium derived from differentiated HC11 cell cultures.

Further evidence for dissociation of the process of HC11 cell differentiation and increased IGFBP-5 protein is provided by the experiments described in Fig. 5a and b. Figure $5 \mathrm{a}$ shows that HC11 cells grown to confluence in the absence of EGF and insulin (conditions which do not lead to competence) still retain the ability to respond to DIP treatment by upregulating IGFBP-5 secretion (compare lanes 1 and 2 with lanes 5 and 6, upper panel). Although densitometric analysis of data derived from four separate experiments indicates that the induction of IGFBP-5 following DIP treatment of non-competent cells is decreased $(70 \pm 18 \%$; mean \pm S.D. $) \quad$ compared with the response of competent cells, DIP treatment of non-competent $\mathrm{HC} 11$ cells leads to a negligible increase in $\beta$-casein detected in cell lysates (see lanes 5 and 6 , lower panel) and these findings confirm that upregulation of IGFBP-5 expression is not tightly regulated by cell differentiation. Furthermore, the presence of EGF during DIP treatment of competent cells, which is known to almost completely inhibit $\beta$-casein expression in HC11 cells, see Fig. 5b (lanes 7 and 8, lower panel) and Marte et al. (1995), still allows for the upregulation of IGFBP-5 following DIP treatment 


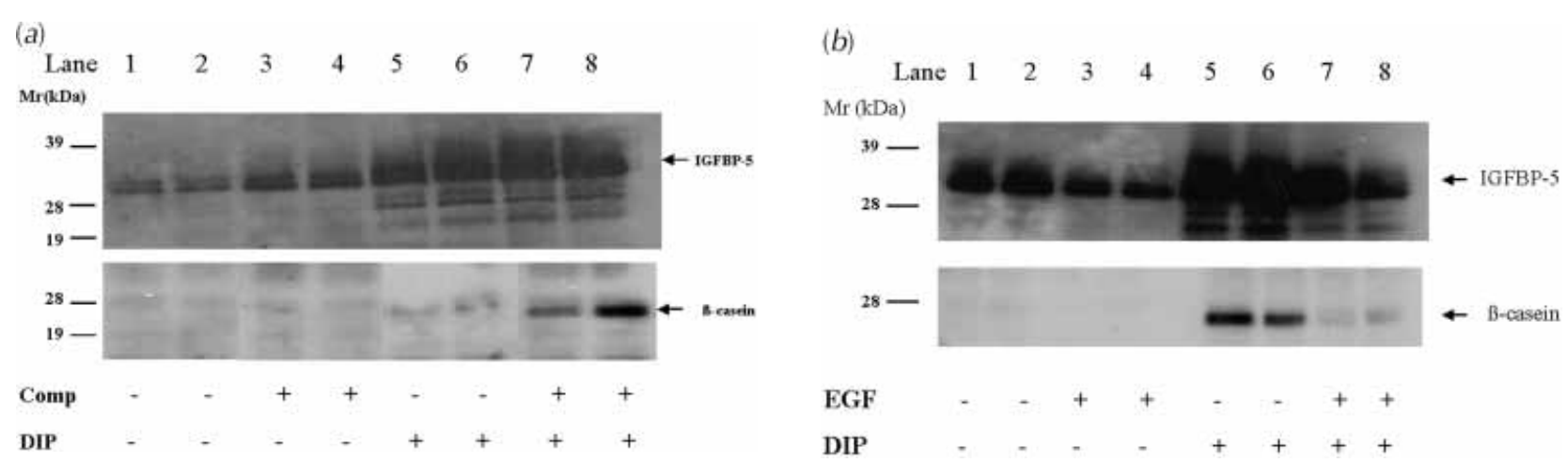

Figure 5 Regulation of IGFBP- 5 secretion and $\beta$-casein synthesis can be dissociated in differentiating HC11 cells. (a) Non-competent HC11 cells upregulate IGFBP-5 secretion in response to DIP treatment. Cells grown and maintained in the absence or presence of EGF and insulin (comp-and comp+ respectively) were subsequently treated \pm DIP for $48 \mathrm{~h}$ followed by Western blot analysis of conditioned medium for IGFBP-5 and cell lysates for $\beta$-casein respectively. This experiment was performed four times and a representative blot is presented.

(b) Competent HC11 cells were treated \pm DIP for $48 \mathrm{~h}$ in the presence or absence of EGF. Conditioned medium and cell lysates were analysed for IGFBP-5 and $\beta$-casein respectively. This experiment was performed four times and a representative blot is shown.

(a)

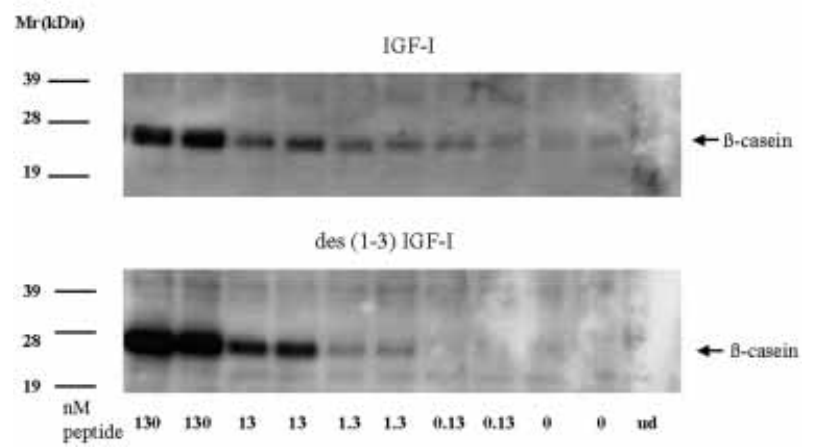

(b)

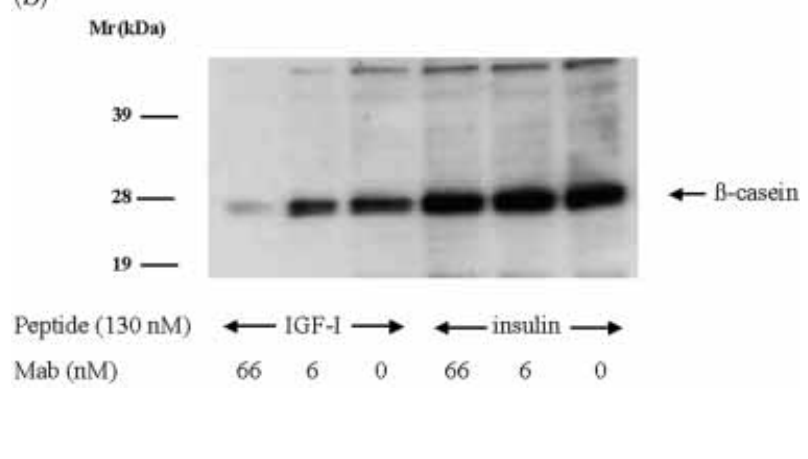

Figure 6 (a) IGF-I can replace insulin as lactogenic hormone. IGF-I or des(1-3) IGF-I was present at the indicated concentrations in the presence of dexamethasone and prolactin. The treatment period was 4 days. Blots of cell lysates were probed for $\beta$-casein as indicated and the results from duplicate wells are presented.

$\mathrm{ud}=\mathrm{undifferentiated}$. This experiment was repeated three times with similar results in each instance. A representative blot is presented. (b) The differentiative effect of IGF-I in HC11 cells occurs through interaction with IGF-IR. HC11 cells were differentiated in the presence of dexamethasone and prolactin containing $130 \mathrm{nM}$ IGF-I or insulin \pm 6 or $66 \mathrm{nM}$ of anti-IGF-IR blocking Mab as indicated. Cell lysates were probed for $\beta$-casein. This experiment was repeated three times and a representative blot is presented.

(Fig. 5b, upper panel - compare lanes 3 and 4 with lanes 7 and 8). Although densitometric analysis of four separate experiments indicates a $50 \pm 28 \%$ (mean \pm S.D.) reduction in IGFBP-5 secretion when EGF is present during DIP treatment of competent cells compared with DIP treatment alone, these experiments provide further evidence that upregulation of IGFBP-5 secretion and the process of cell differentiation are independent.

We also examined the activity of IGF-I and IGF-II in relation to differentiation of HC11 cells. Figure $6 \mathrm{a}$ indicates that, in a similar background of prolactin and dexamethasone, IGF-I is able to substitute for insulin in the differentiation mix. In the experiment shown, IGF-I is most active at the highest concentration examined in this experiment, $130 \mathrm{nM}$. Repeat dose-response curves indicated that insulin was more active than IGF-I in stimulating $\beta$-casein synthesis and that IGF-II had no effect on the expression of this differentiation marker (data not shown). It is possible that the differentiating activity of IGF-I may be compromised by the accumulation of IGFBP- 5 over the 4 day time course of this experiment. Support for 
this theory was provided by the observation that des(1-3) IGF-I (an IGF analogue which has decreased affinity for IGFBPs) was more active than IGF-I at concentrations of 13 and $130 \mathrm{nM}$ in stimulating $\beta$-casein levels in HC11 cell lysates (Fig. $6 \mathrm{a}$, lower panel). Although it appeared that IGF-I was more active in stimulation of $\beta$-casein expression than des(1-3) IGF-I at lower concentrations $(0.13$ and $1.3 \mathrm{nM})$ the signal obtained for the $\beta$-casein protein was weak in these experiments and we believe that these findings may reflect small variations in very low basal expression of $\beta$-casein protein. Support for this conclusion is provided by the observation of a weak signal for $\beta$-casein under basal conditions (no hormone) evident in the upper panel but not the lower panel in Fig. 6a. It is known that IGF-I is able to cross-react at the insulin receptor and it was important therefore to establish whether the effects of IGF-I in stimulating $\beta$-casein synthesis occurred through the insulin receptor or the IGF-IR. In Fig. $6 \mathrm{~b}$ we show that an IGF-IR-specific Mab acts to block the effect of IGF-I but not insulin in stimulating HC11 cell differentiation. Although this suggests that the differentiative effects of these hormones occurs through their homologous cell surface receptors, it is possible that hybrid IGF-I/insulin receptors (Bailyes et al. 1997) exist on the surface of HC11 cells (in addition to insulin receptors) and our data would also be consistent with this particular receptor profile.

\section{Discussion}

In the present study we have clearly demonstrated that during differentiation of HC11 cells, levels of IGFBP-5 protein in conditioned medium increased by up to 10 -fold. The increase in IGFBP-5 secretion seen during differentiation of $\mathrm{HC} 11$ cells is supported by evidence of upregulation of this protein during the differentiation of other cell types. These include Schwann cells (Cheng et al. 1999), mouse osteosarcoma cells (Schneider et al. 2001) and the mouse C2 myoblast cell line where IGFBP-5 is the only IGFBP produced by terminally differentiating cells (James et al. 1993, Rotwein et al. 1995). It is also interesting that a subsequent report from this group (James et al. 1996) using C2 cells stably transfected with an IGFBP-5 expression construct indicated that overexpression of this protein in transfected cells was associated with inhibition of differentiation, lending support to the dual nature of IGFBP-5 action during the process of cell differentiation. We would emphasise, however, that the results of our study (see Fig. 3a and $\mathrm{b}$ and Fig. 5a and b) clearly indicate that upregulation of IGFBP-5 can be dissociated from the process of $\mathrm{HCll}$ cell differentiation. Indeed the observation that undifferentiated $\mathrm{HCll}$ cells secrete substantial quantities of IGFBP-5 also indicates that differentiation and IGFBP profile are uncoupled. This also suggests that IGFBP-5 on its own is not causative for HC11 cell differentiation but this hypothesis requires further investigation for example by using cells in which the IGFBP-5 gene is knocked out. Our observation of downregulation of IGFBP-2 during differentiation of HC11 cells is also supported by observations in other cell culture systems. Downregulation of IGFBP-2 was reported during the retinoic acid-induced differentiation of the human neuroblastoma cell line SK-N-BE(2) (Bernardini et al. 1994), in the C2C12 mouse myoblast cell line (Ernst et al. 1992) and in the human colon adenocarcinoma cell line $\mathrm{CaCo}-2$ (Zhang et al. 1995). Whether the downregulation of IGFBP-2 during the process of cell differentiation is an important mechanistic feature of this process is unknown. We would stress, however, as is the case for IGFBP-5, that the levels of IGFBP-2 in HC11-conditioned medium are not linked to the process of cell differentiation. Indeed the secretion of IGFBP-2 appears to be regulated by an inhibitory effect of dexamethasone and a stimulatory effect of prolactin and is not principally due to the effect of cell differentiation per se. However, the regulation of IGFBP-2 in our cell culture system may be somewhat more complex given the observation that the hormonal combination dexamethasone and prolactin appears to have the same effect as SFM treatment whereas treatment with DIP downregulates IGFBP-2 levels (Fig. 4b). Nonetheless, for both IGFBPs there is a clear dissociation between the process of cell differentiation and the regulation of IGFBP accumulation in conditioned medium.

It is interesting to compare our findings in this mouse mammary epithelial cell line with the reports of increased IGFBP-5 secretion by involuting mouse mammary gland (Tonner et al. 1995, 1997). It could be argued that the observation of IGFBP-5 expression by a differentiating mammary 
epithelial cell line but by involuting mammary gland in vivo (which presumably contains a significant population of epithelial cells which are undergoing apoptosis) is somewhat contradictory, leading to the conclusion that the $\mathrm{HC} 11$ cell line is not an appropriate in vitro model to describe the IGF axis in the rodent mammary gland. However, to our knowledge there have been no definitive studies on IGFBP-5 expression in the developing mammary gland which have examined the expression of this IGFBP in differentiating mammary epithelial cells, although the presence of IGFBP-5 mRNA in terminal end bud structures during postnatal mammary gland development and in ductal and alveolar epithelial cells from mid-pregnant mouse mammary gland has been described (Wood et al. 2000). It is possible that the apoptotic action of IGFBP-5 in vivo is dependent on the very high concentrations of binding protein which accumulate in the involuting mammary gland $(50 \mu \mathrm{g} / \mathrm{ml})$ (Tonner et al. 2002). Whether HC11 cells upregulate IGFBP-5 secretion under conditions of apoptosis as well as during cellular differentiation is the subject of further investigations in our laboratories. It is also clearly of interest to determine whether IGFBP-5 is directly apoptotic on mammary epithelial cells in vitro as it appears to be in vivo (Allan et al. 2002).

There are very few data on the IGF axis in non-tumorigenic mammary epithelial cell lines. An earlier report (Skaar \& Baumrucker 1993) investigating the IGFBP profile in Comma-1D cells (from which HC11 cells are derived, see Introduction) indicated a different IGFBP profile for these cells, which under undifferentiated conditions secreted IGFBP-3 as well as IGFBP-2. We found that undifferentiated HCll cells did not secrete IGFBP-3. A study using primary cultures of mouse mammary epithelial cells cultured on floating collagen gels (Fielder et al. 1992) reported induction of a $29 \mathrm{kDa}$ IGFBP species following treatment with prolactin or mouse placental lactogen. This IGFBP species did not react with antisera to IGFBP-1 or -2 and, although it has to date remained uncharacterised, it is intriguing to speculate that this binding protein is in fact IGFBP-5 and that the lactogen-induced stimulation of IGFBP seen in these primary cultures is a phenotype retained by the HC11 cell line. Further support for this conjecture is provided by the fact that primary mouse mammary epithelial cells used in the above study were derived from mid-pregnant animals and that the HC11 cell line was established from similar mid-pregnant mammary gland tissue. Although we observed that HCll cells secrete IGFBP-2 and -5 it is important to realise that the abundance of these binding proteins (as determined by RIA) varies by three orders of magnitude, with IGFBP-2 present at $\mathrm{ng} / \mathrm{ml}$ concentrations and IGFBP-5 present at $\mu \mathrm{g} / \mathrm{ml}$ concentrations. In addition, although we did not observe any proteolytic activity towards ${ }^{125}$ I-labelled IGFBP-2 or -5 in medium conditioned by either undifferentiated or differentiated HCll cells (data not shown), Western blots of IGFBP-5 in HC11conditioned medium clearly indicate immunoreactive IGFBP-5 fragments (see for example Fig. 1 and Fig. 3a). It is possible that IGFBP-5 is proteolysed by an enzyme activity present on the surface of HC11 cells or a protease(s) which may be associated with the extracellular matrix secreted by HC11 cells. This possibility is under further investigation.

Our observation that IGF-I can replace insulin in the differentiation hormone mix is similar to the findings reported in mammary gland explants derived from mid-pregnant mice by Prosser et al. (1987) who reported that IGF-I would substitute for insulin (in a background of prolactin and hydrocortisone) and stimulate $\beta$-casein mRNA and protein accumulation. In these experiments the $\mathrm{ED}_{50}$ of IGF-I was 10-fold greater than that of insulin (10 vs $1 \mathrm{ng} / \mathrm{ml}$ ). More recently, similar findings have been confirmed in HC11 cells and also in the parental Comma-1D line (Merlo et al. 1996, Lykos et al. 2000) and there is some evidence for the maintenance of differentiated function of alveolar epithelial cells by IGF-I in vivo (Richert \& Wood 1999). In the current study we have provided evidence that the differentiative effect of IGF-I occurs through the homologous IGF-IR and is not due to cross-reactivity of IGF-I at the insulin receptor (see Fig. 6b). Although this indicates that autocrine secretion of IGF-I may potentially induce differentiation of HCl1 cells we have not examined in detail whether medium conditioned by differentiated or undifferentiated HC11 cells contains IGF-I. Whatever the case, treatment of cells with dexamethasone and prolactin alone does not lead to a stimulation of $\beta$-casein synthesis (see Fig. 3a), arguing that either IGF-I is not secreted by HC1 1 cells or is present at levels which are not high 
enough to induce HC11 cell differentiation. Alternatively the relatively high levels of endogenous IGFBP present in HCll cultures in these conditions may act to neutralise any IGF-I which is present (see Fig. 6a). It is also interesting to note that IGF-I is able to replace insulin as a competence factor during growth of HCll cells (Merlo et al. 1996). We found that IGF-II did not stimulate the differentiation of $\mathrm{HCll}$ cells, a finding confirmed by Lykos et al. (2000) for the parental cell line Comma-1D. This group in fact reported an inhibitory effect of endogenously produced IGF-II on $\beta$-casein expression by these cells. IGF-II is reported to have a 3 -fold higher affinity for IGFBP-5 than IGF-I (Kiefer et al. 1992) and this fact together with its 2- to 3-fold lower affinity for the IGF-IR (Braulke 1999) may partly explain a lack of activity in this culture system.

In conclusion we have demonstrated that the mouse mammary epithelial cell line HC11 demonstrates an IGFBP profile which is independent of the state of cellular differentiation. Although IGFBP-5 is upregulated during differentiation of cells induced by treatment with the DIP lactogenic hormone mix, binary combinations of these hormones also increase levels of IGFBP-5 but do not stimulate the synthesis of the differentiation marker $\beta$-casein. In addition, the ability of non-competent HC11 cells to upregulate IGFBP-5 expression following DIP challenge and also the continued upregulation of IGFBP-5 levels in the concurrent presence of EGF during DIP-induced differentiation support the conclusion that IGFBP-5 regulation is dissociated from $\mathrm{HC} 11$ cell differentiation. In addition we have shown that IGF-I will act most probably through its cognate receptor to stimulate differentiation of competent HC11 cell cultures. We are currently examining whether the IGFBPs secreted by HCil cells have any mechanistic involvement in the differentiation of this cell line.

\section{Acknowledgements}

The authors would like to thank Dr Ernst Reichmann for rabbit anti-mouse $\beta$-casein antibody, Dr Roger Clegg, Hannah Research Institute, for purified rat $\beta$-casein and Nancy Nelson for assistance with RIA. MAP is a joint UK-Korea Chevening research scholar. JL holds a BBSRC
CASE research studentship. This work was also funded by the Scottish Executive, Environment and Rural Affairs Department (SEERAD).

\section{References}

Allan GJ, Tonner E, Barber MC, Travers MT, Shand JH, Vernon RG, Kelly PA, Binart N \& Flint DJ 2002 Growth hormone, acting in part through the insulin-like growth factor axis, rescues developmental, but not metabolic, activity in the mammary gland of mice expressing a single allele of the prolactin receptor. Endocrinology 143 4310-4319.

Andress DL 1998 Insulin-like growth factor-binding protein-5 (IGFBP-5) stimulates phosphorylation of the IGFBP-5 receptor. American Fournal of Physiology 274 E744-E750.

Bailyes EM, Nave BT, Soos MA, Orr SR, Hayward AC \& Siddle K 1997 Insulin receptor/IGF-I receptor hybrids are widely distributed in mammalian tissues: quantification of individual receptor species by selective immunoprecipitation and immunoblotting. Biochemical fournal 327 209-215.

Ball RK, Friis RR, Schoenenberger CA, Doppler W \& Groner B $1988 a$ Prolactin regulation of beta-casein gene expression and of a cytosolic $120-\mathrm{kd}$ protein in a cloned mouse mammary epithelial cell line. EMBO Fournal 7 2089-2095.

Ball RK, Ziemiecki A, Schonenberger CA, Reichmann E, Redmond SM \& Groner B $1988 b$ v-myc alters the response of a cloned mouse mammary epithelial cell line to lactogenic hormones. Molecular Endocrinology 2 133-142.

Bernardini S, Cianfarani S, Spagnoli A, Annicchiarico-Petruzzelli M, Melino G, Messoud R, Boscherini B, Finazzi-Agro A, Rosenfield RG \& Federici G 1994 Expression and down-regulation by retinoic acid of IGF binding protein-2 and -4 in medium from human neuroblastoma cells. Fournal of Neuroendocrinology 6 409-413.

Boney CM, Moats-Staats BM, Stiles AD \& D'Ercole AJ 1994 Expression of insulin-like growth factor-I (IGF-I) and IGF-binding proteins during adipogenesis. Endocrinology 135 1863-1868.

Bonnette SG \& Hadsell DL 2001 Targeted disruption of the IGF-I receptor gene decreases cellular proliferation in mammary terminal end buds. Endocrinology 142 4937-4945.

Bramani S, Allan GJ \& Beattie J 1999 Characterization of the IGF axis in a rat liver-derived epithelial cell line. Growth Hormone and IGF Research 9 425-433.

Braulke T 1999 Type-2 IGF receptor: a multi-ligand binding protein. Hormone and Metabolic Research 31 242-246.

Chammas R, Taverna D, Gella N, Santos C \& Hynes NE 1994 Laminin and tenascin assembly and expression regulate HC11 mouse mammary cell differentiation. Fournal of Cell Science $\mathbf{1 0 7}$ $1031-1040$.

Cheng HL, Shy M \& Feldman EL 1999 Regulation of insulin-like growth factor-binding protein-5 expression during Schwann cell differentiation. Endocrinology $1404478-4485$.

Clemmons DR 1998 Role of insulin-like growth factor binding proteins in controlling IGF actions. Molecular and Cellular Endocrinology 140 19-24.

Danielson KG, Oborn CJ, Durban EM, Butel JS \& Medina D 1984 Epithelial mouse mammary cell line exhibiting normal morphogenesis in vivo and functional differentiation in vitro. PNAS $813756-3760$.

Ernst CW, McCusker RH \& White ME 1992 Gene expression and secretion of insulin-like growth factor-binding proteins during myoblast differentiation. Endocrinology 130 607-615.

Fielder PJ, Thordarson G, English A, Rosenfeld RG \& Talamantes F 1992 Expression of a lactogen-dependent insulin-like growth factor-binding protein in cultured mouse mammary epithelial cells. Endocrinology 131 261-267. 
Flint DJ, Tonner E \& Allan GJ 2000 Insulin-like growth factor binding proteins: IGF-dependent and -independent effects in the mammary gland. Fournal of Mammary Gland Biology and Neoplasia $\mathbf{5}$ 65-73.

Fraker PJ \& Speck JC Jr 1978 Protein and cell membrane iodinations with a sparingly soluble chloroamide, 1,3,4,6-tetrachloro-3 $\alpha, 6 \alpha$-diphenylglycoluril. Biochemical and Biophysical Research Communications 80 849-857.

Hadsell DL, Greenberg NM, Fligger JM, Baumrucker CR \& Rosen JM 1996 Targeted expression of des(1-3) human insulin-like growth factor I in transgenic mice influences mammary gland development and IGF-binding protein expression. Endocrinology 137 321-330.

Hossenlopp P, Seurin D, Segovia-Quinson B, Hardouin S \& Binoux M 1986 Analysis of serum insulin-like growth factor binding proteins using western blotting: use of the method for titration of the binding proteins and competitive binding studies. Annals of Biochemistry 154 138-143.

James PL, Jones SB, Busby WH Jr, Clemmons DR \& Rotwein P 1993 A highly conserved insulin-like growth factor-binding protein (IGFBP-5) is expressed during myoblast differentiation. Fournal of Biological Chemistry 268 22305-22312.

James PL, Stewart CE \& Rotwein P 1996 Insulin-like growth factor binding protein-5 modulates muscle differentiation through an insulin-like growth factor-dependent mechanism. Fournal of Cell Biology 133 683-693.

Jones JI, Gockerman A, Busby WH Jr, Camacho-Hubner C \& Clemmons DR 1993 Extracellular matrix contains insulin-like growth factor binding protein-5: potentiation of the effects of IGF-I. Journal of Cell Biology $121679-687$.

Kanatani M, Sugimoto T, Nishiyama K \& Chihara K 2000 Stimulatory effect of insulin-like growth factor binding protein-5 on mouse osteoclast formation and osteoclastic bone-resorbing activity. Fournal of Bone Mineral Research 15 902-910.

Kiefer MC, Schmid C, Waldvogel M, Schlapfer I, Futo E, Masiarz FR, Green K, Barr P \& Zapf J 1992 Characterization of recombinant human insulin-like growth factor binding proteins 4 , 5, and 6 produced in yeast. Fournal of Biological Chemistry 267 12692-12699.

Kleinberg DL 1998 Role of IGF-I in normal mammary development. Breast Cancer Research and Treatment 47 201-208.

LeRoith D, Neuenschwander S, Wood TL \& Henninghausen L 1995 Insulin-like growth factor-I and insulin-like growth factor binding protein-3 inhibit involution of the mammary gland following lactation: studies in transgenic mice. Progress in Growth Factor Research 6 433-436.

Lykos MA, Fligger JM, Staley MD \& Baumrucker CR 2000 Autocrine insulin-like growth factor II inhibits beta-casein mRNA expression in a mammary cell line. Fournal of Dairy Science $\mathbf{8 3}$ 285-295.

Marte BM, Jeschke M, Graus-Porta D, Taverna D, Hofer P, Groner B, Yarden Y \& Hynes NE 1995 Neu differentiation factor/heregulin modulates growth and differentiation of HC1 1 mammary epithelial cells. Molecular Endocrinology 9 14-23.

McCaig C, Perks CM \& Holly JM 2002 Signalling pathways involved in the direct effects of IGFBP-5 on breast epithelial cell attachment and survival. Fournal of Cellular Biochemistry 84 784-794.

Merlo GR, Graus-Porta D, Cella N, Marte BM, Taverna D \& Hynes NE 1996 Growth, differentiation and survival of HC11 mammary epithelial cells: diverse effects of receptor tyrosine kinase-activating peptide growth factors. European Fournal of Cell Biology 70 97-105.

Neuenschwander S, Schwartz A, Wood TL, Roberts CT Jr, Henninghausen L \& LeRoith D 1996 Involution of the lactating mammary gland is inhibited by the IGF system in a transgenic mouse model. Fournal of Clinical Investigation 97 2225-2232.
Prosser CG, Sankaran L, Hennighausen L \& Topper YJ 1987

Comparison of the roles of insulin and insulin-like growth factor I in casein gene expression and in the development of alpha-lactalbumin and glucose transport activities in the mouse mammary epithelial cell. Endocrinology 120 1411-1416.

Richert MM \& Wood TL 1999 The insulin-like growth factors (IGF and IGF type I receptor during postnatal growth of the murine mammary gland: sites of messenger ribonucleic acid expression and potential functions. Endocrinology $140454-461$.

Richman C, Baylink DJ, Lang K, Dony C \& Mohan S 1999 Recombinant human insulin-like growth factor-binding protein-5 stimulates bone formation parameters in vitro and in vivo. Endocrinology 140 4699-4705.

Rotwein P, James PL \& Kou K 1995 Rapid activation of insulin-like growth factor binding protein-5 gene transcription during myoblast differentiation. Molecular Endocrinology 9 913-923.

Ruan W \& Kleinberg DL 1999 Insulin-like growth factor I is essential for terminal end bud formation and ductal morphogenesis during mammary development. Endocrinology 140 5075-5081.

Ruan W, Newman CB \& Kleinberg DL 1992 Intact and amino-terminally shortened forms of insulin-like growth factor I induce mammary gland differentiation and development. PNAS $\mathbf{8 9}$ 10872-10876.

Schneider MR, Zhou R, Hoeflich A, Krebs O, Schmidt J, Moha S, Wolf E \& Lahm H 2001 Insulin-like growth factor-binding protein-5 inhibits growth and induces differentiation of mouse osteosarcoma cells. Biochemical and Biophysical Research Communications $288435-442$.

Schneider MR, Wolf E, Hoeflich A \& Lahm H 2002 IGF-binding protein-5: flexible player in the IGF system and effector on its own. Fournal of Endocrinology 172 423-440.

Skaar TC \& Baumrucker CR 1993 Regulation of insulin-like growth factor binding protein secretion by a murine mammary epithelial cell line. Experimental Cell Research 209 183-188.

Tonner E, Quarrie L, Travers M, Barber M, Logan A, Wilde C \& Flint DJ 1995 Does an IGF-binding protein (IGFBP) present in involuting rat mammary gland regulate apoptosis? Progress in Growth Factor Research 6 409-414.

Tonner E, Barber MC, Travers MT, Logan A \& Flint DJ 1997 Hormonal control of insulin-like growth factor-binding protein-5 production in the involuting mammary gland of the rat. Endocrinology 138 5101-5107.

Tonner E, Allan G, Shkreta L, Webster J, Whitelaw CB \& Flint DJ 2000 Insulin-like growth factor binding protein-5 (IGFBP-5) potentially regulates programmed cell death and plasminogen activation in the mammary gland. Advances in Experimental and Medical Biology 480 45-53.

Tonner E, Barber MC, Allan GJ, Beattie J, Webster J, Whitelaw CB \& Flint DJ 2002 Insulin-like growth factor binding protein-5 (IGFBP-5) induces premature cell death in the mammary glands of transgenic mice. Development 129 4547-4557.

Wood TL, Richert MM, Stull MA \& Allar MA 2000 The insulin-like growth factors (IGFs) and IGF binding proteins in postnatal development of murine mammary glands. Fournal of Mammary Gland Biology and Neoplasia 5 31-42.

Yamanaka Y, Fowlkes JL, Wilson EM, Rosenfeld RG \& Oh Y 1999 Characterization of insulin-like growth factor binding protein-3 (IGFBP-3) binding to human breast cancer cells: kinetics of IGFBP-3 binding and identification of receptor binding domain on the IGFBP-3 molecule. Endocrinology 140 1319-1328.

Zhang Y, Wick DA, Seetharam B \& Dahms NM 1995 Expression of IGF-II and IGF binding proteins in differentiating human intestinal Caco-2 cells. American Fournal of Physiology $\mathbf{2 6 9}$ E804-E813.

Received in final form 14 March 2003 Accepted 20 March 2003 